doi: 10.32620/oikit.2019.84.09

УДК 629.735.33.015:4:004.942

В.М. Онищенко

\title{
Математичне моделювання удару пружного літального апарата на посадці
}

\author{
Національний аерокосмічний університет ім. М.Є. Жуковського \\ «Харківський авіаційний інститут»
}

\begin{abstract}
Показано розвиток напрямку, орієнтованого на створення і випереджальне функціонування математичних моделей (ММ) літальних апаратів (ЛА) - їх математичних дублерів на прикладі розрахунку динаміки удару і навантаження пружного літака на посадці. Відзначено актуальність такого підходу в процесі проектування і експлуатації ЛА в силу трудомісткості і обмежених можливостей наземних експериментальних установок і льотного експерименту. На прикладі легкого літального апарата наводяться результати застосування спрощеної MM і чисельного розрахунку на ЕOM динаміки удару i навантаження пружної конструкції при посадці. Визначення динамічної реакції ЛА i навантаження пружної конструкції при посадці відноситься до актуальної задачі динамічної аеропружності. У статті наведені основні рівняння, що використовуються для побудови ММ пружного літака з нелінійним шасі. Визначені основні параметри, які характеризують навантаження конструкції. Приведені результати розрахункового аналізу удару літака, проведені широкі параметричні дослідження щодо впливу ряду конструктивних і експлуатаційних фракторів на динамічні процеси, проаналізовані закономірності та особливості удару і навантаження пружного літального апарата на посадці. Показано, що навантаження треба визначати з урахуванням пружних коливань конструкції. Динамічні навантаження від пружних коливань є суттєвими за величиною і, як виявляється, найчастіше визначають міцність планера і шасі. Підкреслено, що умовою застосування розрахункового методу $є$ сорормовані математичні моделі функціонування ЛА і наявність інформації щодо літального апарата - масовоінерційних, жорсткісних і аеродинамічних характеристик.

Ключові слова: математичне моделювання, узагальнені координати, демпфірування в конструкції, динамічні характеристики, форми та частоти власних коливань, динамічне навантаження.
\end{abstract}

Вступ. Посадка ЛА є одним із відповідальних і небезпечних етапів польоту. За частки секунди сили при ударі сягають значних величин, в елементах планера і шасі від цих сил діють значні прискорення, в конструкції ЛА збуджуються механічні коливання [1].

Визначення динамічної реакції ЛА і навантаження пружної конструкції при посадці відноситься до актуальної задачі аеропружності [3]. Динамічні навантаження в деяких випадках настільки важкі для конструкції, що необхідно вживати заходів щодо їх зниження. Внаслідок складності задання динамічних навантажень теоретичним шляхом на практиці все частіше звертаються до математичного моделювання посадки на ЕОМ.

В роботі [2] представлені результати ММ динаміки удару і навантаження ЛА при зльоті і посадці. Застосування спрощених ММ (без урахування пружності конструкції) представлено в [4].

Постановка завдання дослідження. Застосувати розрахунковий метод для оцінки пружних коливань і навантаження конструкції при посадці на основі математичних моделей функціонування ЛА різного рівня складності.

Реалізація поставленого завдання. Створення ММ динаміки удару ЛА при посадці передбачає синтез даних нестаціонарної аеродинаміки, теорії 
пружності і коливань, а також рівнянь динаміки польоту і нелінійних співвідношень для амортизації шасі.

Аеродинамічне навантаження, сили тяжіння та реакція поверхні аеродрому визначають динаміку руху ЛА. Рівняння руху центру мас літака i обертання навколо нього в процесі посадки ЛА мають вигляд

$$
m_{Л A} \frac{d \stackrel{\prime}{V}}{d t}=\stackrel{r}{R_{a}}+\stackrel{r}{R_{u}}+\stackrel{r}{P}+\stackrel{r}{G} ; \quad \frac{d \dot{\prime}}{d t}=\stackrel{r}{M_{Л A}},
$$

де $\stackrel{\prime}{R}_{a}, \stackrel{\prime}{R}_{u}, \stackrel{\prime}{P}, \stackrel{\prime}{G}$ - головні вектори аеродинамічних сил, реакції поверхні аеродрому, тяги двигунів, сили тяжіння; $K$ - головний момент кількості руху твердого ЛА; $\vec{M}_{\text {ЛА }}$ - головний момент відносно центру мас зовнішніх сил.

Нестаціонарні аеродинамічні сили на посадці визначаються на основі гіпотези квазістаціонарності.

При побудові ММ аеропружності ЛА деформація конструкції розкладається за власними фрункціями, що відображають пружні властивості конструкції в інтегральному сенсі. Дефрормацію ЛА розкладають за симетричними та кососиметричними формами вільних коливань конструкції. Будь-який переріз балки має вертикальне переміщення $y(z, t)$ і кут повороту $\vartheta(z, t)$. Переміщення перерізу несучої поверхні записується у вигляді добутку форм власних коливань на узагальнені координати $q(t)$, що залежать тільки від часу:

$$
y(z, t)=\sum_{i=1}^{N} f_{i}(z) q_{i}(t) ; \quad \vartheta(z, t)=\sum_{j=1}^{N} \varphi_{j}(z) q_{j}(t),
$$

де $N$ - число тонів власних коливань, що утримуються.

Для адекватного моделювання взаємодії планера і шасі в процесі удару ЛА проводиться декомпозиція системи і розглядаються сумісні диференційні рівняння пружних коливань планера і динаміки стойок шасі.

Пружні коливання конструкції ЛА визначаються 3 системи $n$ сумісних диференціальних рівнянь

$$
\ddot{q}_{k}+2 \chi_{k} \omega_{k} \dot{q}_{k}+\omega_{k}^{2} q_{k}=Q_{k} / M_{k}(k=1,2, \ldots, n) .
$$

де $Q_{k}-$ узагальнена робота сил і моментів; $M_{k}-$ узагальнена маса системи; $\omega_{k}-$ власна частота $k$-го тону коливань; $\chi_{k}-$ коефріцієнт конструкційного демпфірування $k$ - го тону.

Узагальнена робота визначається від дії реакцій кожного $j$ - го амортизатора (сили $P_{y j}$ і моменту $M_{z j}$ ), погонних аеродинамічних сил і моментів і складає

$$
Q_{\kappa}=\int_{0}^{l_{\sigma}} f_{\kappa}(z) q_{\text {повв }}(z) d z+\sum_{j} P_{y_{j}} f_{\kappa u_{j}}\left(z_{j u}\right)+\int_{0}^{l_{\sigma}} \varphi_{\kappa}(z) m_{\text {пов }}(z) d z .+\sum_{j} M_{z_{j}} \varphi_{\kappa}\left(z_{j u}\right) \text {. }
$$

Сили $P_{y j}$ і моменти $M_{z j}$, що діють з боку амортизаторів шасі, розраховуються з урахуванням кінематичних параметрів руху ЛА і роботи амортизації шасі.

Розглянемо легкий літак, на якому встановлене трьохопорне шасі 3 носовим колесом, на основному стояку шасі використовується ресора, однорідне крило має постійну вздовж розмаху погонну масу і жорсткість на 
згинання. Літак здійснює посадку на основні стояки шасі (розглядається випадок $E_{\text {ш }}^{\prime}$, удар симетричний).

Для визначення навантаження пружного легкого ЛА з моменту часу $t=0$ (колеса торкаються полоси) сумісно вирішується система диференціальних рівнянь пружних коливань, рівняння руху мас літака і деформування ресор. Деформацію ЛА розкладаємо за симетричними формами вільних коливань конструкції (утримуються п'ять нижчих тонів згинальних коливань).

На рис. 1 показано зміну першої та другої узагальнених координат. Чисельно вони дорівнюють відхиленню кінця крила в процесі удару. Як видно, внесок першої узагальненої координати в деформування крила $є$ визначальним. Легко бачити, що низькочастотні коливання $q_{1}(t)$ відбуваються з частотою обтиснення амортизації шасі, а високочастотні - 3 першою власною частотою згинальних коливань крила. Внаслідок недостатнього демпфірування в системі (ресорах шасі) має місце відокремлення опорних елементів від полоси (ділянки $a-b, c-d$ i $e-f$ ).

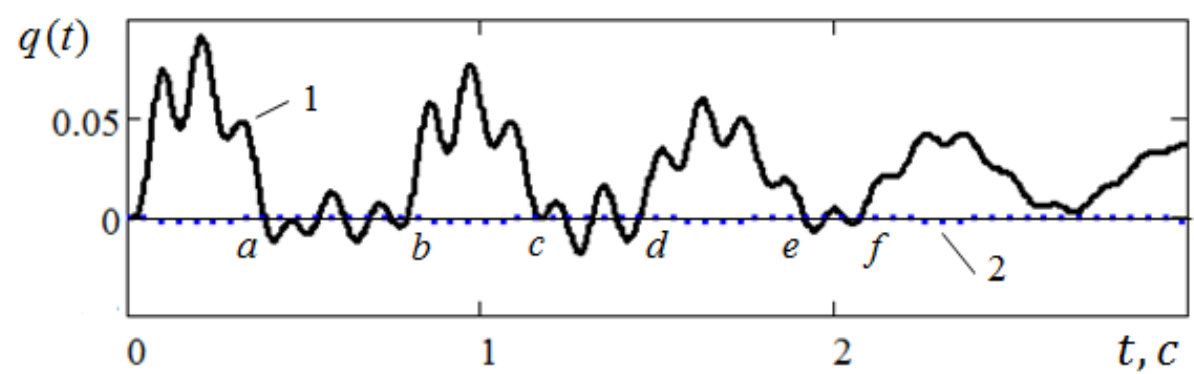

Рис. 1. Зміну першої та другої узагальнених координат

На рис. 2 зображено прискорення кінця крила для двох випадків погонної маси: вихідної 1 і для маси, збільшеної втричі - 2. Як видно, навантаження ЛА на посадці має складний динамічний характер.

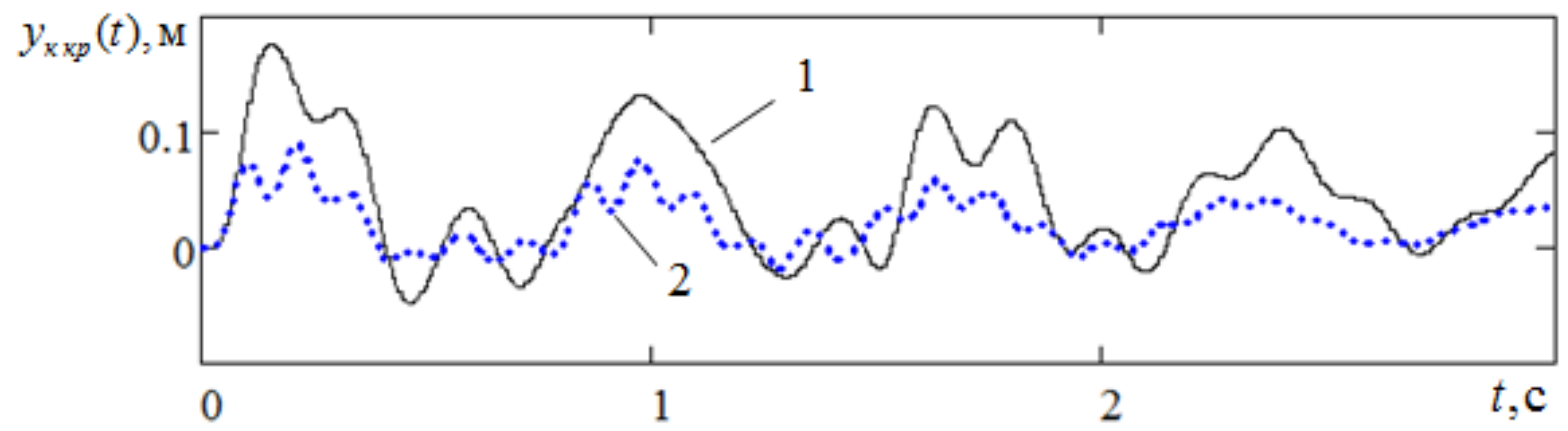

Рис. 2. Прискорення кінця крила для двох випадків погонної маси

Створена математична модель динаміки удару ЛА на посадці дозволяє аналізувати динаміку та навантаження літака, проводити параметричні дослідження щодо впливу на міцність експлуатаційних і конструктивних чинників.

Відмітимо, що ММ динамічної реакції ЛА мають ффункціонувати паралельно зі створенням ЛА і постійно вдосконалюватися. 


\section{Список літератури}

1. Кузнецов, О. А. Динамические нагрузки на самолет [Текст]/ О.А. Кузнецов. - М.: Изд-во фриз. - мат. лит., 2008. - 264 с.

2. Снисаренко Т. В., Чубань В.Д. Математическое моделирование динамических нагрузок при взлете и посадке упругого самолета [Текст] / Т.В. Снисаренко, В.Д. Чубань. // Ученые записки ЦАГИ, том XXXIX, №3 - М.: 2008. $63-76 \mathrm{c}$.

3. Бисплингхофрф, Р. Л. Аэроупругость [Текст] / Р. Л. Бисплингхофрфр, Х. Эшли, Р. Л. Хелфмен. - М. : Изд-во иностр. лит., 1958. - 799 с.

4. Онищенко В. М. Вільні та вимушені коливання конструкції літального апарата з декількома степенями вільності [Текст] : навч. посіб. / В. М. Онищенко. - Харків: ХАИ, 2019. - 184 с.

\section{References}

1. Kuznetsov, O.A. Dynamycheskye nahruzky na samolet [Dynamic loads on the plane]. Moscow, 2008. 264 p.

2. Snysarenko T.V., Chuban' V.D. Matematycheskoe modelyrovanye dynamycheskykh nahruzok pry vzlete y posadke upruhoho samoleta [Mathematical modeling of dynamic loads during takeoff and landing of an elastic aircraft]. Moscow. Uchenue zapysky TsAHY, 2008, vol. XXXIX, no. 3 . pp. 63 - 76.

3. Bysplynhkhoff, R. L. Aэroupruhost' [Aeroelasticity Moscow, 1958. 799 p.

4. Onyshchenko V.M. Vil'ni ta vymusheni kolyvannya konstruktsiyi lital'noho aparata $z$ dekil'koma stepenyamy vil'nosti [Free and forced fluctuations of the design of the aircraft with several degrees of freedom]. Kharkiv, KhAY, 2019. 184 p.

Надійшла до редакції 5.06.2019, розглянута на редколегії 10.06.2019

\section{Математическое моделирование удара упругого летательного аппарата при посадке}

Показано развитие направления, ориентированного на создание и совершенствование математических моделей (MM) летательных аппаратов (ЛА) - их математических дублеров на примере расчета динамики удара и нагружения упругого самолета при посадке. Актуальность такого подхода при проектировании и эксплуатации летательных аппаратов обусловлена сложностью и ограниченными возможностями наземных экспериментальных установок и летного эксперимента. На примере легкого самолета представлены результаты применения упрощенной ММ и численного расчета на ЭВМ динамики удара и нагружения упругой конструкции при посадке. Определение динамической реакции самолета и нагружения упругой конструкции при посадке относится к актуальной проблеме динамической аэроупругости. В статье приведены основные уравнения, используемые для построения ММ упругого самолета с нелинейным шасси. Определены основные параметры, характеризующие нагруженность конструкции. Представлены результаты расчетного анализа удара самолета, проведены параметрические исследования влияния ряда конструктивных и эксплуатационных фракторов на динамические процессы, проанализированы закономерности и особенности удара и нагружения упругого самолета на посадке. Показано, что нагрузки следует определять с учетом упругих колебаний конструкции. Динамические 
нагрузки от упругих колебаний значительны по величине и, как выясняется, чаще всего определяют прочность планера и шасси. Подчеркивается, что условием применения расчетного метода является наличие математических моделей функционирования самолета и наличие информации о самолете массово-инерционных, жесткостных и аэродинамических характеристик.

Ключевые слова: математическое моделирование, обобщенные координаты, демпфирование в конструкции, динамические характеристики, формы и частоты собственных колебаний, динамическое нагружение.

\section{Mathematical modeling of elastic impact aircraft on landing}

The development of a direction oriented towards the creation and advanced operation of mathematical models (MM) of aircraft - their mathematical doublers on the example of calculating the impact dynamics and loading of an elastic plane on landing is shown. The relevance of such an approach in the design and operation of aircraft due to the complexity and limited capabilities of terrestrial experimental facilities and flight experiment are noted. The example of a lightweight aircraft presents the results of the application of a simplified $M M$ and the numerical calculation of the impact dynamics on the computer and the load of the elastic construction at landing. Determination of the dynamic reaction of the aircraft and the load of the elastic structure at landing refers to the actual problem of dynamic aeroelasticity. In the article the basic equations used to construct the MM of an elastic plane with a nonlinear landing gear are given. The basic parameters that characterize the structural load are determined. The results of the calculation analysis of the impact of the aircraft are presented, extensive parametric studies have been carried out on the influence of a number of constructive and operational factors on dynamic processes, and analyzed the patterns and features of impact and loading of an elastic aircraft on landing. It is shown that the load must be determined taking into account elastic structural vibrations. Dynamic loads from elastic oscillations are significant in magnitude and, as it turns out, most often determine the strength of the glider and the chassis. It is emphasized that the condition of the application of the calculated method is the mathematical models of the operation of the aircraft and the availability of information on the aircraft - mass-inertial, rigid and aerodynamic characteristics.

Key words: mathematical modeling, generalized coordinates, damping in structure, dynamic characteristics, forms and frequencies of free vibrations, dynamic loading.

\section{Відомості про авторів:}

Онищенко Владимир Михайлович - к.т.н., доцент кафедри міцності літальних апаратів, Національний аерокосмічний університет ім. М.Є. Жуковського «Харківський авіаційний інститут», Харків, Україна, vladimironisenk083@gmail.com , ORCID 0000-0002-6547-6646.

\section{About the author:}

Onishchenko Vladimir - Ph.D, Associate Professor, Department of Strength of Aircraft, National Aerospace University named after. M.Ye. Zhukovsky "Kharkiv Aviation Institute", Kharkiv, Ukraine, vladimironisenk083@gmail.com, ORCID 0000 $0002-6547-6646$. 